\title{
Pengaruh Model Pembelajaran Kooperatif tipe Jigsaw Terhadap Motivasi dan Hasil Belajar Peserta Didik Kelas 11 SMAN 1 Banjarmasin
}

Oleh

Muhammad Didi Faujiannor

(Proposal Skripsi)

Untuk memenuhi melaksanakan Penelitian

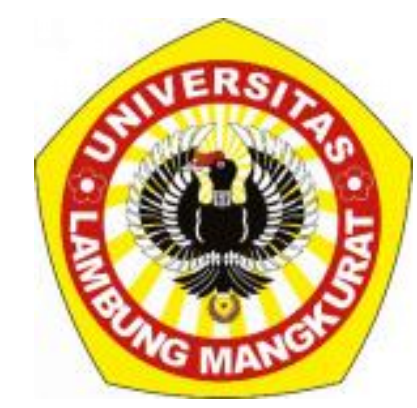

Program Studi Pendidikan Sejarah

Jurusan Ilmu Pengetahuan Sosial

Fakultas Keguruaan dan Ilmu Pendidikan

Universitas Lambung Mangkurat

Banjarmasin

2020 


\section{BAB I}

\section{PENDAHULUAN}

\section{A. Latar Belakang Masalah}

Pendidikan merupakan usaha sadar untuk menyiapkan peserta didik dengan kegiatan bimbingan, latihan, dan pengajaran bagi perannya dimasa yang akan datang. Bentuk pendidikan dengan hadir di sekolah adalah yang paling umum dijumpai di berbagai negara dan daerah. Ada juga sebagian kecil orang tua memilih untuk pendidikan home-schooling (pendidikan di rumah), $e$ learning (pendidikan online) dalam proses pembelajaran.

pembelajaran adalah sebuah proses interaksi peserta didik dengan pendidik dan sumber belajar pada suatu lingkungan belajar. Pembelajaran adalah proses untuk membantu peserta didik agar dapat belajar dengan baik, misalkan saja dalam proses pembelajaran sejarah di setiap sekolah.

Kegiatan pembelajaran sejarah pada umumnya cenderung membuat peserta didik pasif dan terkesan membosankankan, menghafal konsep atau materi yang diberikan oleh guru melalui metode konvesional. Padahal materi sejarah bukan untuk dihapal melainkan dipahami dan mengaplikasikan dari proses pembelajaran

Sistem pembelajaran sejarah yang dikembangkan sebenarnya tidak lepas dari pengaruh budaya yang telah mengakar. Model pembelajaran yang bersifat satu arah dimana guru menjadi sumber pengetahuan utama dalam kegiatan pembelajaran menjadi sangat sulit untuk dirubah. Pembelajaran sejarah saat ini mengakibatkan peran siswa sebagai pelaku sejarah pada zamannya menjadi terabaikan. Pengalaman-pengalaman yang telah dimiliki oleh siswa sebelumnya atau lingkungan sosialnya tidak dijadikan bahan pelajaran di kelas, sehingga menempatkan siswa sebagai peserta pembelajaran sejarah yang pasif (Martanto, dkk, 2009:10). Dengan kata lain, kekurangcermatan pemilihan strategi mengajar akan berakibat fatal bagi pencapaian tujuan pengajaran itu sendiri (Widja, 1989:13). 
Guru-guru Sejarah dari berbagai jenjang pendidikan acapkali mengeluh karena banyak siswa dari kelas-kelas sejarah mereka kurang kalau tidak dapat dikatakan tertarik kepada pengajaran (teaching) dan pembelajaran (learning) mata pelajaran (subject-matter) sejarah. Alasan kalsik, biasanya sejarah itu merupakan hafalan yang membosankan, "cerita" tentang orang-orang ternama, peristiwa-peristiwa, tempat-tempat, waktu lampau (past) yang sama sekali tidak ada hubungannya dengan mereka.

Kebanyakan guru sejarah juga saat melakukan proses pembelajaran sejarah yang menggunakan model pembelajaran kurang tepat. Menurut Hamid Hasan dalam Alfian (2007) bahwa kenyataan yang ada sekarang, pembelajaran sejarah jauh dari harapan untuk memungkinkan anak melihat relevansinya dengan kehidupan masa kini dan masa depan. Pembelajaran sejarah cenderung hanya memanfaatkan fakta sejarah sebagai materi utama. Tidak aneh bila pendidikan sejarah terasa kering, tidak menarik, dan tidak memberi kesempatan kepada anak didik untuk belajar menggali makna dari sebuah peristiwa sejarah.

Dari kegiatan pembelajaran sejarah yang kebanyakan guru menggunakan metode konvesional sehingga para peserta didik mengira bahwa pelajaran sejarah untuk dihapal hal ini menyebabkan kurangnya minat atau motivasi peserta didik terhadap pembelajaran sejarah sehingga akan berdampak terhadap rendahnya akan hasil belajar dalam proses pembelajaran.

Sebenarnya belajar sejarah tidak berhenti disitu saja, melainkan peserta didik diharapkan dapat mengapresiasi (afaktif) apa yang telah dipelajarinya tentang orang-orang, masa-masa dan peristiwa-peristiwa tertentu dari masa lalu. Peserta didik harus mencari makna (meaning) dan belajar suatu kejadian, apakah itu baik buruk buruk. Tahap berikutnya dibawah bimbingan guru tentu saja siswa-siswa perlu mengevaluasi dan mengkritik buku-buku test atau teks-teks sejarah (sebagai sumber pertama).

Agar menjadikan peserta didik aktif dalam proses pembelajaran guru sebagai fasilitatornya adalah dengan cara guru harus kreatif dalam menentukan metode serta model pembelajran agar tujuan dari pembelajaran sejarah tercapai sesuai dengan kurikulum yang berlaku. 
Masalah metode pendidikan adalah suatu masalah yang sangat perlu diperhatikan khususya bagi para pendidik, karena dengan pemilihan metode yang tepat itu akan menetukan keberhasilan seorang peserta didik dalam proses pembelajaran, sebaliknya jika para pendidik menggunakan pemilihan metode yang tidak tepat atau tidak efektif maka akan menyebabkan pembelajaran yang monoton dan kurang berhasil.

Untuk dapat kembali mengajarkan sejarah secara baik dan menarik, pendidik mempunyai keleluasaan mengolah dan menata materi yang ada. Sudah barang tentu tidak mungkin topik yang ada dalam kurikulum dapat diselesaikan dengan alokasi waktu yang tersedia. Untuk itulah bagaimana pendidik mengontrol berbagai materi pengajaran yang memungkinkan dipelajari di luar kelas. Kurikulum yang baik untuk kelas tertentu adalah yang cocok, terencana dengan baik, sesuai, menyajikan pemikiran yang bijaksana dan sistematis. Tujuan kurikulum adalah membuka peluang melalui perencanaan yang bijaksana bagi tumbuhkembangnya mata pelajaran dan peserta didik (Hariyono, 1995:172 ; Kochar, 2008:68).

Agar adanya suasana belajar yang menyenangkan bagi peserta didik dalam proses pembelajaran maka seorang guru harus mengetahui cara-cara atau metode yang harus diterapkan, sehingga peserta didik termotivasi untuk mengikuti kegiatan pembelajaran. Oleh karena itu peserta didik perlu adanya metode atau model pengajaran yang berbasis permainan di samping terpenuhinya kebutuhan akan permainan dan hiburan, kebutuhan akan pengetahuan juga akan terpenuhi lewat penyampaian materi yang menggunakan metode permainan, salah satunya adalah model pembelajaran kooperatif bertipe Jigsaw

Model pembelajaran kooperatif adalah rangkaian kegiatan belajar yang dilakukan peserta didik dalam kelompok-kelompok tertentu untuk mencapai tujuan pembelajaran yang dirumuskan. Pembelajaran kooperatif ini merupakan salah satu bentuk pembelajaran yang berdasarkan paham kontruktivis. Dalam pembelajaran kooperatif diterapkan strategi belajar dengan sejumlah peserta didik sebagai anggota kelompok kecil yang tingkat kemampannya berbeda. 
Jigsaw didesain untuk meningkatkan tanggung jawab peserta didik terhadap pembelajarannya dan pembelajaran orang lain. Selain itu, untuk meningkatkan tanggung jawab, peserta didik secara mandiri dituntut memiliki saling kebergantungan yang positif (saling memberi tahu) terhadap teman sekelompoknya.

Dalam pembelajaran kooperatif tipe jigsaw, peserta didik tipe Jigsaw, peserta didik lebih mudah menemukan dan memahami konsep-konsep yang sulit apabila mereka saling mendiskusikan masalah-masalah tersebut tersebut dengan temannya.

Model pembelajaran kooperatif tipe Jigsaw memiliki dampak positif terhadap proses kegiatan belajar mengajar, yakni meningkatkan aktivitas guru dan siswa selama proses pembelajaran, meningkatkan ketercapaian TKP, dan meningkatkan minta serta motivasi peserta didik yang akan memperngaruhi hasil belajar.

Dengan demikian dapat disimpulkan untuk mencapai hasil pembelajaran yang maksimal serta tercapainya tujuan pembelajaran dengan kurikulum maka peneliti tertarik untuk mengkaji lebih dalam tentang "Pengaruh Model Pembelajaran Kooperatif Tipe Jigsaw Terhadap Motivasi dan Hasil Belajar Peserta Didik Kelas 11 SMAN 1 Banjarmasin”.

\section{B. Identifikasi Masalah}

1. Kebanyakan guru sejarah yang menggunakan Metode Konvesional yang menyebabkan kurang aktif nya peserta didik dalam proses pembelajaran sejarah

2. Kurangnya minat serta motivasi belajar peserta didik terhadap pembelajaran sejarah sehingga menyebabkan hasil belajar sejarah 


\section{Batasan Masalah}

Masalah ini dibatasi sampai dengan penerapan atau penggunaan model pembelajaran kooperatif tipe Jigsaw agar menciptakan suasana yang menyenangkan dalam proses pembelajaran sejarah agar meningkatnya minat serta motivasi peserta didik yang akan mempengaruhi hasil belajar.

\section{Rumusan Masalah}

1. Bagaimana upaya guru untuk menciptakan suasana pembelajaran yang menyenangkan dalam proses pembelajaran sejarah ?

2. Bagaimana penerapan Model Pembelajaran Kooperatif tipe Jigsaw agar bisa meningkatkan minat serta motivasi dan hasil belajar peserta didik ?

3. Apakah penerapan model pembelajaran kooperatif tipe jigsaw bisa meningkatkan minta serta motivasi dan hasil belajar peserta didik.?

\section{E. Tujuan Penelitian}

1. Mengetahui upaya guru untuk menciptakan suasana pembelajaran yang menyenangkan dalam proses pembelajaran sejarah.

2. Mengetahui penerapan Model Pembelajaran Kooperatif tipe Jigsaw agar bisa meningkatkan minat serta motivasi dan hasil belajar peserta didik.

3. Mengetahui penerapan model pembelajaran kooperatif tipe jigsaw bisa meningkatkan minta serta motivasi dan hasil belajar peserta didik.

\section{F. Manfaat Penelitian}

\section{Manfaat Teoritis}

Memberikan suatu kontribusi berupa pengetahuan yang telah dtperoleh melalui penelitian tentang pengaruh model pembelajaran Kooperatif tipe Jigsaw terhadap motivasi dan hasil belajar k sebagai bahan tambahan atau referensi untuk bagi peniliti yang akan datang khususnya untuk penelitian pembelajaran sejarah. 


\section{Manfaat Praktis}

- Bagi pendidik dan calon pendidik

$\checkmark$ Memberikan masukan terhadap pendidik atau calon pendidik tentang model pembelajaran yang efektif dalam pembelajaran agar meningkatkan motivasi dan hasil belajar.

$\checkmark$ Memberikan masukan cara menerapkan model pembelajaran kooperatif tipe jigsaw untuk mata pelajaran sejarah

- Bagi Peneliti

Menambahkan wawasan serta pengalaman penulis ketika terlihat langsung sebagai guru dalam menerapkan model pembelajaran yang efektif khusunya model pembelajaran kooperatif tipe jigsaw.

- Bagi peserta didik

Peserta didik sebagai subyek penelitian, diharapkan dapat memperoleh pengalaman langsung mengenai pembelajaran secara aktif, kreatif dan menyenangkan melalui model pembelajaran kooperatif tipe jigsaw. Sehingga meningkatnya motivasi belajar peserta didik mempelajari sejarah.

- Bagi Sekolah

Sebagai bahan pertimbangan dalam menyusun program pembelajaran serta menentukan metode dan media pembelajaran yang tepat untuk meninggkatkan motivasi dan hasil belajar peserta didik. 


\section{BAB II}

\section{Kajian Pustaka}

\section{A. Kajian Teori}

\section{Defenisi Pembelajaran Kooperatif tipe Jigsaw}

Pembelajaran kooperatif ini merupakan salah satu bentuk pembelajaran yang berdasarkan paham kontruktivis. Dalam pembelajaran kooperatif diterapkan strategi belajar dengan sejumlah peserta didik sebagai anggota kelompok kecil yang tingkat kemampannya berbeda.

Model pembelajaran kooperatif tipe jigsaw merupakan model pembelajaran yang mampu mengajak siswauntuk berpikir secara aktif dan kreatif dalamproses pembelajaran. Model ini tidak hanya mengembangkan kemampuan intelektual tetapi seluruh potensi yang ada, termasuk pengembangan emosional dan pengembangan keterampilan. Dengan menerapkan model pembelajaran ini akan melatih peserta didik berani mengemukaan pendapat, bekerja sama, mengembangkan diri, dan bertanggung jawab secara individu,saling ketergantungan positif, interaksipersonal dan proses kelompok.

Pada model pembelajaran Kooperatif tipe jigsaw, terdapat sekelompok asal dan kelompok ahli. Kelompok asal yaitu kelompok kelompok induk peserta didik yang beranggotakan peserta didik dengan kemampuan asal, dan latar belakang keluarga yang beragam. Adapun kelompok ahli, yaitu kelompok peserta didik yang terdiri atas anggota kelompok asal yang berbeda, yang ditugaskan untuk mempelajari dan mendalami topic-topik tertentu dan menyelasaikan tugas-tugas yang berhubungan dengan topik nya, kemudian menjelaskam kepada anggota kelompok asal.

Dari penjelasan tersebut dapat diketahui bahwa model pembelajaran kooperatif jigsaw adalah model pembelajaran yang mendorong siswa lebih aktif, dimana siswa, bukan guru yang memiliki tanggung jawab 
lebih besar dalam melaksanakan pembelajaran, siswa dituntut bekerja sama positif dimana setiap anggota bertanggung jawab untuk mempelajari masalah tertentu dari materi yang diberikan dan menyampaikan materi atau mengajarkan materi tersebut kepada anggota kelompok yang lain.

\section{Langkah Penggunaan Model Pembelajaran Kooperatif tipe Jigsaw}

\begin{tabular}{|c|c|}
\hline Langkah-Langkah & Peran Guru \\
\hline $\begin{array}{l}\text { Langkah 1: } \\
\text { Menyampaikan tujuan } \\
\text { memotivasi peserta didik }\end{array}$ & $\begin{array}{l}\text { Menyampaikan semua tujuan } \\
\text { yang ingin dicapai selama } \\
\text { pembelajaran dan memberikan } \\
\text { motivasi peserta didik untuk } \\
\text { belajar }\end{array}$ \\
\hline $\begin{array}{l}\text { Langkah } 2 \text { : } \\
\text { Menyajikan informasi }\end{array}$ & $\begin{array}{l}\text { Menyajikan informasi kepada } \\
\text { peserta didik dengan jalan } \\
\text { demonstrasi atau melalui bahan } \\
\text { bacaan. }\end{array}$ \\
\hline $\begin{array}{l}\text { Langkah } 3 \text { : } \\
\text { Mengorganisasikan peserta didik } \\
\text { kedalam kelompok-kelompok } \\
\text { belajar }\end{array}$ & $\begin{array}{l}\text { Menjelaskan kepada peserta } \\
\text { didik cara membentuk kelompok } \\
\text { belajar dan membantu setiap } \\
\text { kelompok agar melakukan } \\
\text { transisi secara effisien. }\end{array}$ \\
\hline $\begin{array}{l}\text { Langkah } 4 \text { : } \\
\text { Membimbing kelompok bekerja } \\
\text { dan belajar }\end{array}$ & $\begin{array}{l}\text { Membimbing kelompok belajar } \\
\text { pada saat peserta didik } \\
\text { mengerjkan tugasnya }\end{array}$ \\
\hline $\begin{array}{l}\text { Langkah } 5 \text { : } \\
\text { Evaluasi }\end{array}$ & $\begin{array}{l}\text { Mengevaluasi hasil belajar } \\
\text { tentang materi yang telah } \\
\text { dipelajari/meminta presentasi } \\
\text { hasil belajar kepada kelompok. }\end{array}$ \\
\hline
\end{tabular}




\begin{tabular}{|l|l|}
\hline $\begin{array}{l}\text { Langkah 6: } \\
\text { Memberikan penghargaan }\end{array}$ & $\begin{array}{l}\text { Menghargai upaya dan hasil } \\
\text { belajar individu dan kelompok }\end{array}$ \\
\hline
\end{tabular}

Dalam pembelajaran kooperatif tipe jigsaw, peserta didik lebih mudah memahami konsep yang sulit apabila mereka saling mendiskusikan masalah-masalah tersebut dengan temannya. Melalui diskusi, akan terjadinya elaborasi kognitif yang baik sehingga dapat meningkatkan daya nalar dan meningkatkan keterlibatan peserta didik dalam pembeljaran, serta memberikan kesempatan kepada peserta didik untuk mengemukakan pendapatnya.

Interaksi social yang dilakukan oleh peserta didik untuk materi yang diberikan kepadanya, dan bertanggung jawab mejelaskan kepada anggota kelompoknya, jadi peserta didik dilatih untuk berani berinteraksi dengan teman temannya.

Untuk melihat pendekatan dalam model pembelajaran kooperatif tipe jigsaw

\begin{tabular}{|c|c|}
\hline Aspek & Jigsaw \\
\hline Tujuan Kognitif & Informasi akademik sederhana \\
\hline Tujuan social & Kerja kelompok dan kerja sama \\
\hline Struktur kelompok & $\begin{array}{l}\text { Kelompok belajar heterogen } \\
\text { dengan 5-6 orang anggoa, } \\
\text { menggunakan pola "kelompok } \\
\text { asal" dan "kelompok ahli" }\end{array}$ \\
\hline Pemilihan topic pelajaran & Biasanya guru \\
\hline Tugas utama & $\begin{array}{l}\text { Peserta didik mempelajari dalam } \\
\text { kelompok ahli kemudian } \\
\text { membantu kelompok asal } \\
\text { mempelajari materi }\end{array}$ \\
\hline Penilaian & $\begin{array}{l}\text { Bervaariasi, dapat berupa tes } \\
\text { mingguan }\end{array}$ \\
\hline Pengakuan & Publikasi lain \\
\hline
\end{tabular}


Keseluruhan aspek kooperatif yang dilakukan oleh peserta didik selama pembelajaran yang berorientasi kooperatif merupakan bagian dari pendidikan akhlak atau moral peserta didik. Dengan demikian dapat disimpulkan bahwa model pembelajaran kooperatif adalah rangkaian kegiatan belajar yang dilakukan peserta didik dengan kelompok.

\section{Keterkaitan Teori belajar Kontrukvisme dengan model} pembelajaran Kooperatif tipe jigsaw

Konstruktivisme merupakan salah satu aliran filsafat pengetahuan yang menekankan bahwa pengetahuan merupakan hasil konstruksi (bentukan). Pengetahuan selalu merupakan akibat dari suatu konstruksi kognitif dari kenyataan yang terjadi melalui aktivitas seseorang. Teori belajar konstruktivistik biasanya dimulai dari karakteristik manusia masa depan yang diharapkan, konstruksi pengetahuan, proses belajar menurut teori konstruktivistik.

Esensi dari teori konstruktivistik adalah peserta didik harus menemukan dan mentransformasikan suatu informasi kompleks ke situasi lain, dan apabila dikehendaki, informasi itu menjadi milik mereka sendiri. Sehingga dalam proses belajar, siswa membangun sendiri pengetahuan mereka dengan keterlibatan aktif dalam kegiatan belajar mengajar. Teori ini lebih menekankan perkembangan konsep dan pengertian yang mendalam, pengetahuan sebagai konstruksi aktif yang dibuat siswa. Jika seseorang tidak aktif membangun pengetahuannya, meskipun usianya tua tetap saja tidak akan berkembang pengetahuannya. Suatu pengetahuan dianggap benar bila pengetahuan itu berguna untuk menghadapi dan memecahkan persoalan atau fenomena yang sesuai. Pengetahuan tidak bisa ditransfer begitu saja, melainkan harus diinterpretasikan sendiri oleh masing-masing orang. Hakikat pembelajaran konstruktivistik oleh Brooks \& Brooks dalam Degeng mengatakan bahwa pengetahuan adalah non-objective, 
bersifat temporer, selalu berubah, dan tidak menentu. Belajar dilihat sebagai penyusunan pengetahuan dari pengalaman konkrit, aktivitas kolaboratif, dan refleksi serta interpretasi

Menurut pandangan konstruktivistik belajar merupakan suatu proses pembentukan pengetahuan. Pembentukan ini harus dilakukan individu yang belajar. Peserta didik harus aktif melakukan kegiatan, aktif berfikir, menyusun konsep dan memberi makna tentang hal-hal yang dipelajari. Paradigma konstruktivistik memandang peserta didik sebagai pribadi yang memiliki kemampuan awal sebelum mempelajari sesuatu pengetahuan yang baru. Bagi kontruktivistik, kegiatan belajar adalah kegiatan aktif mahasiswa untuk menemukan sesuatu dan membangun sendiri pengetahuannya.

Pendekatan konstruktivistik dalam model pembelajaaran kooperatif tipe jigsaw menekankan bahwa peranan utama dalam kegiatan belajar adalah aktivitas peserta didik dalam mengkonstruksi pengetahuannya sendiri. Segala sesuatu seperti bahan, peralatan, lingkungan dan fasilitas lainnya disediakan untuk membantu pembentukan tersebut. Mahasiswa diberi kebebasan untuk mengungkapkan pendapat dan pemikirannya sendiri tentang sesuatu yang dihadapi. Dengan cara demikian peserta didik akan terbiasa dan terlatih untuk berfikir kritis, kreatif, dan mampu mempertanggungjawabkan pemikirannya secara rasional.

Dalam pembelajaran kooperatif tipe jigsaw aktivitas-aktivitas pembelajaran meliputi mengamati fenomena-fenomena, mengumpulkan data-data, merumuskan dan menguji hipotesishipotesis, dan bekerja sama dengan orang lain. Kegiatan lainnya adalah mengajak peserta didik mengunjungi lokasi-lokasi di luar ruangan kelas. Guru-guru dari berbagai disiplin ilmu diperlukan untuk merencanakan kurikulum bersama-sama. Peserta didik perlu diarahkan untuk dapat mengatur diri sendiri dan berperan aktif dalam pembelajaran mereka dengan menentukan tujuan-tujuan, memantau dan mengevaluasi kemajuan mereka, dan bertindak melampaui standar-standar yang 
disyaratkan bagi mereka dengan menelusuri hal-hal yang menjadi motivasi belajar mereka.

\section{Aplikasi Teori Belajar Sibernetik dalam model pembelajaran kooperatif tipe Jigsaw}

Teori sibernetik adalah bahwa tidak ada satu proses belajarpun yang ideal untuk segala situasi, dan yang cocok untuk semua siswa. Sebab cara belajar sangat ditentukan oleh sistem informasi. Sebuah informasi mungkin akan dipelajari oleh seorang siswa dengan satu macam proses belajar, dan informasi yang sama mungkin akan dipelajari siswa lain melalui proses belajar yang berbeda.

Pembelajaran berdasarkan teori belajar sibernetik adalah usaha guru untuk membantu siswa mencapai tujuan belajarnya secara efektif dengan cara memfungsikan unsur- unsur kognisi siswa, terutama unsur pikiran untuk memahami stimulus dari luar melalui proses pengolahan informasi. Proses pengolahan informasi adalah sebuah pendekatan dalam belajar yang mengutamakan berfungsinya memori.

Dalam pembelajaran kooperatif, guru memberikan stimulus berupa kuis atau pertanyaan- pertanyaan sebagai tes kemampuan prasyarat siswa, sehingga siswa aktif berfikir. Dan belajar menurut sibernetik adalah pengolahan informasi oleh siswa. Pengolahan informasi ini terjadi karena adanya stimulus dari guru yang berupa informasi.

Belajar bukan sesuatu yang bersifat alamiah, namun terjadi dengan kondisi- kondisi tertentu, yaitu kondisi internal dan kondisi eksterna Kondisi internal peserta didik yang mempengaruhi proses belajar melalui proses pengolahan informasi dan yang sangat penting untuk diperhatikan oleh seorang guru dalam mengelola pembelajaran. 


\section{Motivasi Belajar}

Motivasi belajar adalah proses yang memberi semangat belajar, arah, dan kegigihan perilaku. Artinya, perilaku yang termotivas iadalah perilaku yang penuh energi, terarah dan bertahan lama" (Suprijono,2009: 163). Dari penjelasan tersebutdapat diketahui bahwa motivasi belajar adalah suatu proses yang membuat peserta didik bersemangat dan menunjuk kan kegigihan nya dalam mencapai arah dan tujuan proses belajar yang dialami nya.

Motivasi belajar menurut Uno (2006:23) adalah dorongan dari dalam diri (internal) dan dari luar diri (eksternal) pada peserta didik siswa yang sedang belajar untuk mengadakan perubahan tingkah laku, pada umumnya dalam motivasi ada beberapa indikator yang mendukung. Hal ini mempunyai peranan besar dalam keberhasilan seorang siswa dalam belajar.

Untuk meningkatkan motivasi dan hasil belajar peserta didik, guru diharapkan mampu menerapkan model-model pembelajaran yang mampu meningkatkan partisipasi peserta didik dalam proses pembelajaran sehingga secara langsung mampu meningkatkan hasil belajar peserta didik.

Hasil penelitian Vansteenkiste et al (2009) membuktikan, bahwa motivasi yang berkualitas bagus dapat ditingkatkan dengan menciptakan iklim pengajaran yang memiliki karakteristik dukungan tinggi terhadap otonomi, struktur, dan keterlibatan peserta didik yang dapat menjadi kontribusi dalam proses kepuasan kebutuhan. Penelitian Cheang (2009) pun memberikan hasil bahwa pendekatan pembelajaran yang berpusat pada siswa (learner-centered approach) efektif dalam meningkatkan beberapa domain motivasi dan strategi pembelajaran.

Motivasi belajar siswa berperan penting terhadap hasil belajar siswa, karena apabila motivasi belajar peserta didik tinggi akan berpengaruh terhadap hasil belajar siswa akan menjadi tinggi begitu juga sebaliknya apabila motivasi belajar peserta didik rendah akan berpengaruh terhadap 
hasil belajar peserta didik akan menjadi rendah. Hal ini peran guru sangat penting untuk menumbuhkan motivasi belajar siswa di kelas, supaya hasil belajar peserta didik maksimal.

\section{Hasil Belajar}

Hasil belajar adalah kemampuan-kemampuan yang dimiliki siswa setelah menerima pengalaman belajarnya. Kemampuan-kemampuan tersebut mencakup aspek kognitif, afektif, dan psikomotorik. Hasil belajar dapat dilihat melalui kegiatan evaluasi yang bertujuan untuk mendapatkan data pembuktian yang akan menunjukkan tingkat kemampuan peserta didik dalam mencapai tujuan pembelajaran.

Horward Kingsley membagi tiga macam hasil belajar, yaitu keterampilan dan kebiasaan, pengetahuan dan pengertian, sikap dan cita-cita. Masing-masing jenis hasil belajar tersebut dapat diisi dengan bahan yang telah diterapkan dalam kurikulum. Sedangkan Gagne membagi lima kategori hasil belajar, yaitu informasi verbal, keterampilan intelektual, strategi kognitif, sikap, danketerampilan motoris.

Hasil belajar pengetahuan termasuk kognitif tingkat rendah yang paling rendah. Namun, tipe hasil belajar ini menjadi prasarat bagi tipe hasil belajar berikutnya. Hasil belajar yang lebih tinggidari pada pengetahuan adalah pemahaman. Dalam taksonomi Bloom, kesanggupan memahami setingkat lebih tinggi dari pada pengethauan. Namun, tidaklah berarti bahwa pengetahuan tidak perlu ditanyakan sebab, untuk dapat memahami, perlu terlebih dahulu mengetahui dan mengenal.

Hasil belajar afektif pada siswa dalam berbagai tingkah laku seperti perhatiannya terhadap pelajaran, disiplin, motivasi belajar, menghargai guru dan teman sekelas, kebiasaan belajar, dan hubungan sosial. Dalam hal ini, penilaian sikap lebih ditujukan untuk membina perilaku sesuai 
budi pekerti dalam rangka pembentukan karakter peserta didik sesuai dengan proses pembelajaran.

Hasil belajar psikomotor ini sebenarnya merupakan kelanjutan dari hasil belajar kognitif (memahami sesuatu) dan dan hasil belajar afektif (yang baru tampak dalam bentuk kecenderungan-kecenderungan berperilaku).

\section{B. Kerangka Pikir Penelitian (Pola berpikir)}

Proses pembelajaran dengan menggunakan model yang tepat merupakan salah satu faktor yang mempengaruhi hasil belajar siswa. Model pembelajaran merupakan salah satu strategi atau cara yang digunakan guru dalam proses pembelajaran secara sistematis untuk mencapai hasil yang dikehendaki.

Karena kurangnya minat peserta diidk dalam mata pelajaran sejarah. Peserta didik cenderung individual dalam proses pembelajaran, peserta didik cenderung pasif ketika pembelajaran berlangsung dan lebih mengandalkan evaluasi dari guru sehingga mengakibatkan materi pembelajaran disampaikan berulang-ulang an siswa masih terpusat pada guru. Oleh karena itu, perlu adanya upaya yang dilakukan guru dalam mengatasi permasalahan tersebut.

Salah satu upaya untuk merancang iklim belajar yang menyenangkan di kelas sehingga meningkatkan keaktifan peserta didik adalah penggunaan model pembelajaran yang menarik. Salah satu jenis model pembelajaran tersebut adalah model pembelajaran Cooperative Learningtipe Jigsaw.

Model pembelajaran Cooperative Learningtipe Jigsawdalam penelitian ini diterapkan pada kelas eksperimen. Kelas eksperimen merupakan kelas yang diberikan treatment. untuk mengetahui terdapat pengaruh yang signifikan atau tidak model pembelajaran Cooperative tipe Jigsaw terhadap motivasi dan hasil belajar peserta didik. Kerangka berpikir dapat dilihat pada gambar berikut 


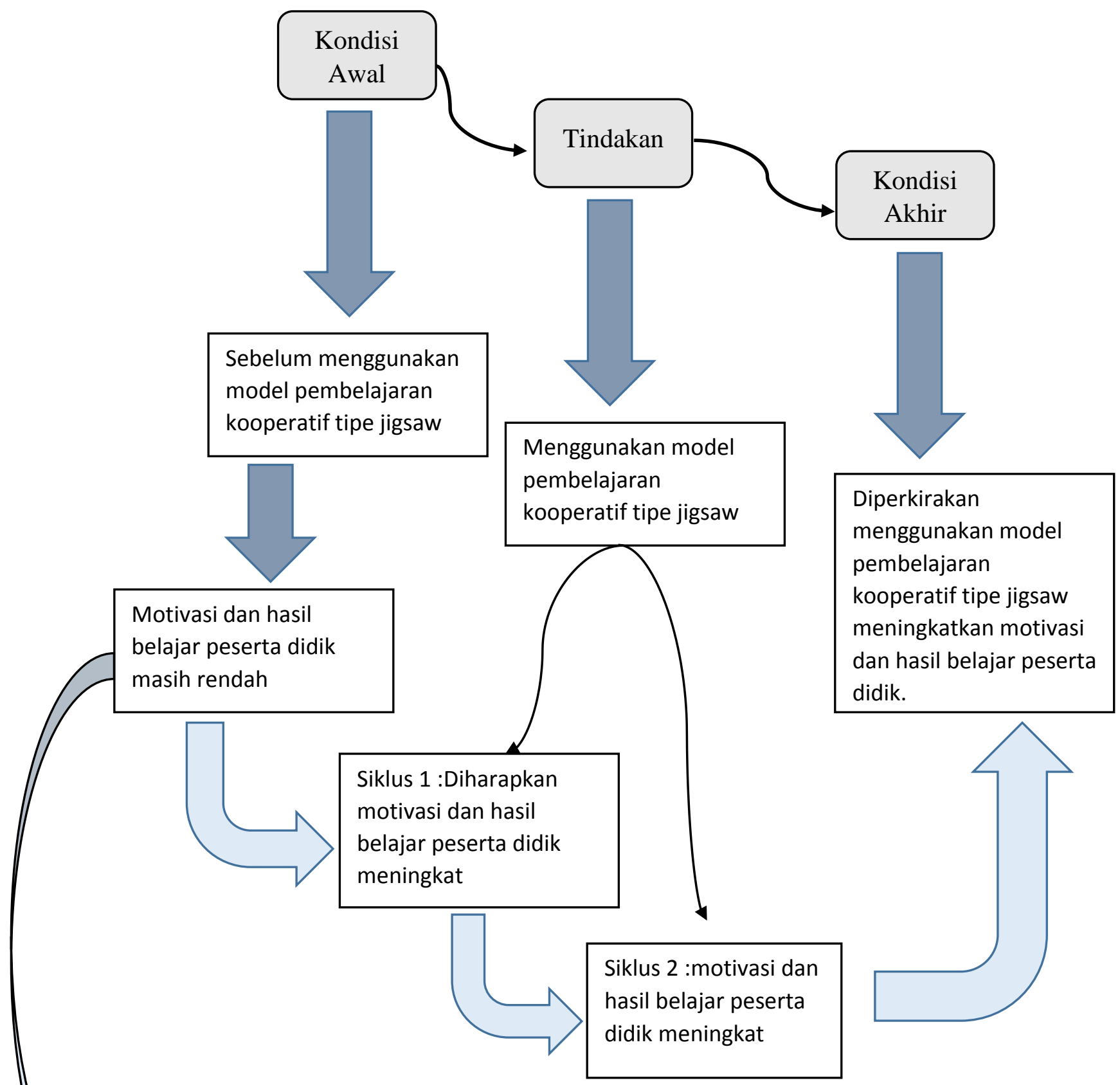

Penyebab :

1. Kebanyakan menggunakan metode konvesional

2. Pembelajaran yang berpusat pada guru (teacher center).

3. Kegiatan pembelajaran yang sebatas hanya menulis dan mendengarkan.

4. Pengalaman belajar siswa yang kurang sehingga peserta didik kurang terlatih memecahkan masalah sendiri, pasif dikelas 
Kondisi awal guru sebelum menggunakan strategi jigsaw dalam pembelajaran sejarah, maka motivasi dan hasil belajar siswa pada mata pelajaran sejarah masih rendah.Untuk memperbaiki dan meningkatkan motivasi dan hasil belajar sejarah perlu adanya tindakan yang dilakukan oleh peneliti yaitu dengan menggunakan strategi jigsaw. Siklus I menggunakan model pembelajaran kooperatif tipe jigsaw tanpa bimbingan guru dan siklus II menggunakan pembelajaaran kooperatif tipe jigsaw dengan bimbingan guru. Dengan tindakan yang Menggunakan strategi jigsaw SIKLUS I: Diharapkan motivasi dan hasil belajar meningkat.

KONDISI AWAL Belum menggunakan model pembelajaran kooperatif tipe jigsaw Motivasi dan hasil belajar murid rendah KONDISI AKHIR SIKLUS II: Motivasidan hasil belajar meningkat berbeda dari siklus I ke siklus II diharapkan motivasi dan hasil belajar siswa pada mata pelajaran sejarah meningkat.Kondisi akhir diduga dengan menggunakan model pembelajaran kooperatif tipe jigsaw dapat meningkatkan motivasidan hasil belajar peserta didik pada mata pelajaran Sejarah Kelas 11 SMAN 1 Banjarmasin.

\section{Hipotesis Penelitian}

Berdasarkan landasan teori dan kerangka pemikiran di atas dapat dirumuskan hipotesis sebagai berikut: "pengaruh model pembelajaran kooperatif tipe jigsaw terhadap motivasi dan hasil belajar peserta didik kelas 11 SMAN 1 Banjarmasin”. 


\section{BAB III}

\section{METODE PENELITIAN}

\section{A. Jenis dan Pendekatan Penelitian}

Jenis penelitian yang digunakan adalah penelitian lapangan (field research), yaitu peneliti terjun langsung ke lapangan untuk mencari dan mengumpulkan data. Dalam penelitian ini pendekatan yang dilakukan adalah pendekatan kualitatif, yaitu data yang dikumpulkan bukan berupa angka-angka, melainkan data tersebut berasal ari observasi, wawancara, dokumentasi, sehingga yang menjadi penilaian ini adalah ingin menggambarkan realita empirik di balik fenomena secara mendalam, rinci dan tuntas.

\section{B. Subjek Peneltian}

Subjek penelitian pengaruh model pembelajaran kooperatif terhadap motivasi dan hasil belajar ini difokuskan pada peserta didik kelas XI IPS SMA Negeri 1 Banjarmasin. Pada kelas tersebut ditemukan adanya permasalahan-permasalahan dalam proses pembelajaran khususnya mata pelajaran Sejarah.

\section{Sumber Data}

Data yang dikumpulkan dalam kegiatan penelitian adalah deskripsi keadaan pembelajaran yang sebenarnya. Data yang diperoleh yaitu berupa keadaan pada saat berlangsungnya proses pembelajaran, hasil observasi berdasarkan lembar observasi, wawancara dengan guru dan peserta didik, pemberian angket motivasi belajar guna menggambarkan kegiatanpem belajaran di dalam kelas tersebut.

\section{Infroman}

Penelitian tindakan kelas ini yang menjadi informan adalah guru mata pelajaran Sejarah kelas XI IPS SMA Negeri 1 Banjarmasin. data 
yang diperlukan berupa tingkat motivasi peserta didik, nilai ulangan (hasil belajar) peserta didik saat penerapan model kooperatif tipe Jigsaw.

\section{Tempat dan Lokasi}

Tempat penelitian dilakukan di SMA Negeri 1 Banjarmasin. Lokasi penelitian tentunya di dalam kelas.

\section{Peristiwa}

Melalui pengamatan pada peristiwa atau aktivitas, peneliti bisa mengetahui proses bagaimana sesuatu yang terjadi secara langsung. Peristiwa dalam penelitian iniadalah proses kegiatan belajar mengajar mata pelajaran sejarah kelas XI MA Negeri 1 SBanjarmasin.

\section{Dokumen atau Arsip}

Dokumen atau arsip juga merupakan sumber data yang penting artinya dalam penelitian tindakan kelas, dokumen dan arsip sebagai sumber data yang dapat membantu penelitian dalam mengumpulkan data penelitian yang ada kaitannya dengan permasalahan dalam penelitian tindakan kelas. Yaitu berupa silabus, RPP,buku referensi mengajar dan hasil evaluasi belajar siswa kelas XI IPS SMAN 1 Banjarmasin.

\section{Teknik Pengumpulan Data}

Penelitian tindakan kelas dalam penelitian ini dilaksanakan untuk memperbaiki proses pembelajaran di kelas khususnya untuk meningkatkan motivasi dan hasil belajar peserta didik pada mata pelajaran Sejarah di SMA Negeri 1 Banjarmasin kelas XI IPS melalui model pembelajaran kooperatif tipe Jigsaw.

Teknik pengumpulan data dalam penelitian ini dapat dijelaskan sebagai berikut:

\section{Observasi}

Observasi dilakukan untuk memantau proses dan dampak pembelajaran yang diperlukan untuk menata langkah-langkah perbaikan agar lebih efektif dan efisian. Pengamatan yang dilakukan yaitu dengan 
berperan serta secara pasif. Pengamatan ini dilakukan terhadap guru ketika melaksanakan kegiatan belajar mengajar dikelas dan kinerja peserta didik selama proses belajar mengajar berlangsung.

Pengamatan terhadap guru diarahkan pada kegiatan guru dalam menjelaskan pelajaran, memotivasi peserta didik, mengajukan pertanyaan dan menanggapi jawabansiswa, mengelola kelas, memberikan umpan balik dan melakukan penilaian terhadap hasil belajar siswa. pengamatan terhadap peserta didik yaitu pada motivasi belajar yang dapar dilihat dari keaktifan bertanya, mempelajari materi, adanya usaha untuk mengerjakan tugas yang diberikan guru dan perhatian terhadap mata pelajaran Sejarah.

Jadi observasi ini bertujuan untuk mengamati kegiatan yang dilakukan guru dan peserta didik dalam proses pembelajaran Sejarah di kelas XI IPS SMA Negeri 1 Banjarmasin. Melalui observasi ini diharapkan dapatmengetahui hambatan ataupun kendala dalam perencanaan tindakan sehinggadapat diperbaiki perencanaan pembelajaran sebelum berjalan lebih lanjut.

\section{Angket}

Angket yang diberikan kepada peserta didik untuk mengetahui sejauh mana motivasi belajar peserta didik kelas XI IPS SMA Negeri 1 Banjarmasin terhadap pembelajaran ssejarah dengan diterapkannya model pembelajaran kooperatif tipe Jigsaw. Penyusunan angket menggunakan skala Likert yaitu dengan menggunakan rentang mulai dari pernyataan sangat positif sampai pernyataan sangat negatif, alternatif pilihan jawaban adalah Selalu (SL), Sering (SR), Kadangkadang (KD), tidak pernah (TP). Jenis angket yang digunakan adalah angket tertutup, responden atau peserta didik diminta untuk memilih salah satual ternatif jawaban yang telah disediakan untuk menjawab pertanyaan. 


\section{Tes}

Tes merupakan seperangkat rangsangan atau stimulus yang diberikan kepada seseorangdengan maksud untuk mendapatkan jawaban yang dapat disajikansebagai dasar bagi penetapan skor angka. Tes yang digunakan oleh peneliti untuk memperoleh data tentang hasil belajar materi Sejarah peserta didik kelas XI IPS SMA Negeri 1 Banjarmasin yaitu tes tertulis dan tes dalam kerja kelompok. Hali ni dilakukan untuk mengetahui adanya peningkatan hasil belajar peserta didik setelah dilakukan tindakan.

\section{Dokumentasi}

Dokumentasi merupakan suatu metode untuk memperoleh suatu informasi dengan melihat buku-buku, arsip atau catatan yang berhubungan dengan penelitian. Selain itu dokumentasi ini sebagai sumber data karena dalam banyak hal dapat digunakan untuk menguji, menafsirkan dan juga sebagai bukti dalam penelitian. Dapat dilakukan dengan mencatat atau mengabadikan kegiatan belajar mengajar berupa foto yang menggambarkan situasi pembelajaran Sosiologi dikelas XI IPS SMA Negeri 1 Banjarmasin. Teknik pengumpulan data melalui dokumen resmi yaitu silabus, RPP dan daftar nilai mata pelajaran sejarah kelas XI IPS2 sebelum dilakukannya tindakan. Dokumen yang digunakan untuk mengetahui perkembangan siswa dalam proses pembelajaran setelah dilakukan tindakan berupa foto

\section{E. Uji Validitas Data}

Penelitian ini menggunakan validitas data dilakukan dengan teknik triangulasi sumber. Adapun penjelasan triangulasi yang digunakan dalam penelitian ini adalah triangulasi sumber merupakan upaya menguji validitas data dilakukan dengan cara mengecek data yang telah diperoleh melalui beberapa sumber. Triangulasi sumber yaitu dengan membandingkan dan mengecek balik derajat kepercayaan suatu informasi yang telah diperoleh melalui berbagai sumber meliputi: 
1. Pengamatan (observasi) dari proses pembelajaran kooperatif tipeJigsaw.

2. Silabus dan RPP.

3. Tes soal berkaitan dengan materi yang telah disampaikan dengan metode pembelajaran kooperatif tipe Jigsaw.

4. Dokumentasi atau foto-foto pada saat kegiatan belajar mengajar dari pra siklus sampai akhir siklus.

Selain itu pada penelitian ini peneliti juga menggunakan validitas isi untuk memperkuat data. Maka dalam penelitian ini semua pertanyaan yang dibuat oleh peneliti sebagai tes hasil belajar siklus I dan siklus II diuji dengan validitas konten atau isi. Pertanyaan-pertanyaan tersebut di tes sesuai atau tidak sesuai dengan kemapuan, pengetahuan, pelajaran, pengalaman dan latar belakang peserta didik kelas XI IPS SMA Negeri 1 Banjarmasin.

\section{F. Analisis Data}

Data yang dianalisis dalam penelitian ini adalah data tentang motivasi dan hasil belajar peserta didik yang diperoleh selam berlangsungnya penelitian tindakan kelas Teknik analisis ini mengacu pada model analisis yang dikembangkan oleh Miles dan Huberman dalam Iskandar (2009) yang terdiri dari tiga komponen yaitu reduksi data penyajian data dan penarikan kesimpulan. Penjelasannya sebagai berikut

\section{Reduksi data}

Reduksi data pada penelitian di kelas XI IPS SMA Negeri 1 Banjarmasin berlangsung terus menerus selama penelitian berlangsung. Selama pengumpulan data berlangsung terjadilah tahapan reduksi atau pemilihan data selanjutnya membuat ringkasan, mengkode dan menelusuri tema. Pemilihan data yang dikode, mana yang dibuang dan pola-pola mana yang akan diringkas. Reduksi ini berkelanjutan terus sesudah penelitian lapangan sampai laporan akhirtersusun lengkap. 


\section{Penyajian data}

Penyajian data yaitu sekumpulan informasi tersusun yang memberi kemungkinan adanya penarikan kesimpulan dan pengambilan tindakan. Pelaksanaan penelitianpenyajian data yang lebih baik merupakan suatu cara yang utama bagi analisiskualitatif yang valid. Data yang sudah diperoleh di kelas kemudian disajikandalam bentuk tabel, foto, dan grafik yang digunakan peneliti dalam memahamiapa yang sedang terjadi dan apa yang harus dilakukan lebih jauhnya menganalisis atau mengambil keputusan tindakan berdasarkan pemahaman yang diperoleh dari penyajian data.

\section{Penarikan kesimpulan}

Penarikan kesimpulan dilaksanakan dengan membandingkan hasil observasi dalam penbelajaran tersebut. Tes ini dilakukan lebih dari satu kali, jika mengalami peningkatan maka usaha yang dilakukan dikatakan berhasil. Penarikan kesimpulan pada penelitian peserta didik kelas XI IPS SMA Negeri 1 Banjarmasin dilakukan dengan cara berdiskusi dengan guru mata pelajran sejarah tentang hasil akhir yang telah dicapai untuk menetukan langkah penelitian selanjutnya.

a) Motivasi belajar peserta didik

Data motivasi belajar siswa dianalisis melalui hasil observasi dan angket motivasi. Adapun pemberian skor angket disajikan dalam tabel berikut:

\begin{tabular}{|c|c|c|c|}
\hline Pilihan & Pernyataan Positif & Pernyataan Negatif & Skor \\
\hline A & Selalu & Tidak Pernah & 4 \\
\hline B & Sering & Jarang & 3 \\
\hline C & Jarang & Sering & 2 \\
\hline D & Tidak Pernah & Selalu & 1 \\
\hline
\end{tabular}




\section{b) Hasil belajar peserta didik}

Peserta didik dikatakan tuntas hasil belajarnya untuk mata pelajaran Sejarah, jika nilai yang diperoleh adalah kurang dari 71 dan rata-rata kelasnya kurang dari $75 \%$ dari jumlah siswa kelas XI IPS SMA Negeri 1 Banjarmasin memenuhi kriteria ketuntasan minimal.

\begin{tabular}{|c|c|c|}
\hline No & Kriteria & Nilai \\
\hline 1 & Tuntas & $76-100$ \\
\hline 2 & Tidak Tuntas & $0-75$ \\
\hline
\end{tabular}

\section{G. Indikator Kinerja Penelitian}

Menurut Mulyasa (2006: 101) pembelajaran dikatakan berhasil dan berkualitas apabila seluruhnya atau setidak-tidaknya sebagian besar $(75 \%)$ peserta didik terlibat secara aktif baik fisik ataupun mental dalam proses pembelajaran. Penelitian dapat dihentikan apabila setiap indikator dari aspek yang di ukur sudah mencapai target yang ditentukan, sebaliknya jika masing-masing variabel yang di ukur belum memenuhi target capaian maka dilanjutkan siklus berikutnya untuk mencapai target yang telah ditetapkan. Indikator keberhasilan penelitian ini adalah apabila terjadinya peningkatan motivasi dan hasil belajar peserta didik kelas XI IPS SMA Negeri 1 Banjaramsin ketika proses pembelajaran sejarah pada tiap siklus.

Indikator keberhasilan pembelajaran sejarah melalui penerapan model pembelajaran kooperatif tipe Jigsaw dapat disajikan dalam tabel berikut:

\begin{tabular}{|c|c|c|}
\hline $\begin{array}{c}\text { Aspek yang } \\
\text { diukur }\end{array}$ & $\begin{array}{c}\text { Presantase } \\
\text { Peserta didik } \\
\text { yang ditargetkan }\end{array}$ & Cara Mengukur \\
\hline $\begin{array}{c}\text { Motivasi } \\
\text { belajar } \\
\text { peserta didik }\end{array}$ & $75 \%$ & $\begin{array}{l}\text { Diamati saat pembelajaran dengan } \\
\text { menggunakan lembar observasi dan } \\
\text { dihitung dari jumlah peserta didik }\end{array}$ \\
\hline
\end{tabular}




\begin{tabular}{|l|l|l|}
\hline & & $\begin{array}{l}\text { yang memfokuskan perhatian pada } \\
\text { pelajaran serta dapat dilihat dengan } \\
\text { menggunakan angket. }\end{array}$ \\
\hline peserta didik & $75 \%$ & $\begin{array}{l}\text { Diukur dari hasil tes formatif, } \\
\text { dimana peserta didik tersebut lulus } \\
\text { daribatas nilai (KKM) dan dihitung } \\
\text { dari jumlah siswa yang dapat } \\
\text { menjawab dengan benar minimal } \\
75 \% \text { soal pada tes hasil belajar } \\
\text { sejarah }\end{array}$ \\
& & \\
\hline
\end{tabular}

\section{H. Prosedur Penelitian}

Prosedur penelitian merupakan rangkaian tahapan penelitian dari awal hingga akhir penelitian. Penelitian ini merupakan tindakan kelas suatu penelitian yang mengkaji tentang permasalahan dengan ruang lingkup yang tidak terlalu luas berkaitan dengan perilaku seseorang atau kelompok tertentu disertai dengan penelaahan yang diteliti terhadap suatu perlakuan dan mengkaji sampai sejauh manadampak perlakuan dalam rangka mengubah, memperbaiki dan meningkatkan mutu perilaku itu terhadap perilaku yang sedang diteliti. Prosedur penelitian tindakan kelasini terdiri dari 2 siklus (direncanakan 2 siklus) yang masing-masing siklus meliputi perencanaan, pelaksanaan tindakan, observasi dan refleksi.

Tiap siklus dilaksanakan sesuai dengan perubahan yang dicapai, seperti yang telah direncanakan. Adapun prosedur penelitian tindakan kelas sebagai berikut:

\section{Siklus 1}

a) Perencanaan

Tahap perencanaan penelitian meliputi penyusunan beberapa langkah penelitian yang digunakan pada saat penerapan model pembelajaran kooperatif tipe Jigsaw. Ada pun langkahlangkah yang dilakukan pada tahap ini adalah: 
1) Guru menyiapkan silabus dan RPP

2) Guru menyiapakan media pembelajaran yang disesuaikan dengan model pembelajaran yang digunakan.

3) Guru menyiapkan lembar observasi.

4) Guru menyiapkan angket motivasi.

5) Guru menyiapkan soal tes untuk evaluasi hasil belajar.

b) Tindakan

Tahap pelaksanaan tindakan merupakan tahap pelaksanaan model pembelajaran kooperatif tipe Jigsaw, tindakan yang akan dilakukan pada tahap ini adalah sebagai berikut:

1) Guru membagi peserta didik dalam kelompok asal.

2) Guru membagikan materi yang berbeda-beda pada tiap anggota kelompok.

3) Guru menetapkan tiap-tiap anggota dalam kelompok ahli sesuai dengan materi yang telah ditentukan.

4) Guru membimbing dan memonitor diskusi kelompok asal.

5) Siswa belajar dan mendiskusikan dalam kelompok ahli sesuai dengan materi yang telah ditentukan.

6) Peserta didik kembali ke kelompok asal masing-masing dan menyampaikankembali materi yang telah dipelajari bersama kelompok ahli

7) Setelah kembali ke kelompok asal guru kemudian mengevaluasi hasildiskusi kelompok tersebut dan jika kelompok tersebut benar juga aktif maka diberikan nilai reward.

c) Observasi

Pada penelitian ini, peneliti bertindak sebagai observer atau pengamat dalam pelaksaan proses belajar mengajar yang dilakukan oleh guru dan peserta didik serta seluruh kegiatan yang ada di dalamnya sedangkan guru kolaborasi (guru mata pelajaran sejarah) bertugas sebagai pengajar yang menerapkan model pembelajaran kooperatif tipe Jigsaw. Evaluasi pembelajaran diberikan melalui tes 
formatif dan angket motivasi yang dilakukan setelah pemberian materi pelajaran selesai.

d) Tahap Analisis dan Refleksi

Pada tahap ini dilakukan analisis terhadap pelaksanaan proses pembelajaran sejarah serta penguasaan materi yang diwujudkan dalam nilai tes dan motivasi melalui angket. Data yang diperoleh dari beberapa sumber data mencakup informan, tempat, peristiwa dan perilaku serta dokumen yang diperoleh melalui observasi, tes, angket dan dokumentasi. Maka peneliti melakukan analisis data secara kualitatif. Setelah dianalisis peneliti dan guru yang bersangkutan melekukan refleksi sebagai upaya untuk merencanakan tahap tindal lanjut untuk memperbaiki proses pemebelajaran sebelumnya agar mencapai hasil yang lebih baik.

\section{Siklus 2}

a) Perencanaan

Tahap perencanaan penelitian meliputi penyusunan beberapa langkah penelitian yang digunakan pada saat penerapan model pembelajaran koopera tiftipe Jigsaw. Adapun langkahlangkah yang dilakukan pada tahap ini adalah:

1) Guru bersama peneliti mengidentifikasidan merumuskan perbaikan-perbaikan yang perlu dilakukan berdasarkan refleksi pada siklus pertama.

2) Guru menyiapkan silabus dan RPP dengan materi.

3) Guru menyiapakan media pembelajaran yang disesuaikan dengan model pembelajaran yang digunakan.

4) Guru menyiapkan lembar observasi.

5) Guru menyiapkan angket motivasi.

6) Guru menyiapkan soal tes untuk evaluasi hasil belajar 
b) Tindakan

Tahap pelaksanaan tindakan merupakan tahap pelaksanaan model pembelajaran kooperatif tipe Jigsaw, tindakan yang akan dilakukan pada tahap ini adalah sebagai berikut:

1) Guru membagi siswa dalam kelompok asal.

2) Guru membagikan materi yang berbeda-beda pada tiap anggota kelompok.

3) Guru menetapkan tiap-tiap anggota dalam kelompok ahlisesuai denganmateri yang telah ditentukan.

4) Guru membimbing dan memonitor diskusi kelompok asal.

5) Peserta didik belajar dan mendiskusikan dalam kelompok ahli sesuai denganmateri yang telah ditentukan

6) Peserta didik kembali ke kelompok asal masing-masing dan menyampaikankembali materi yang telah dipelajari bersama kelompok ahli.

7) Setelah kembali ke kelompok asal guru kemudian mengevaluasi hasil diskusi kelompok tersebut dan jika kelompok tersebut benar juga aktif maka diberikan nilai reward.

c) Observasi

Pada penelitian ini, peneliti bertindak sebagai observer atau pengamat dalam pelaksaan proses belajar mengajar yang dilakukan oleh guru dan peserta didik sertas eluruh kegiatan yang ada di dalamnya sedangkan guru kolaborasi (guru mata pelajaran sejarah) bertugas sebagai pengajar yang menerapkan model pembelajaran kooperatif tipe Jigsaw. Evaluasi pembelajaran diberikan melalui tes formatif dan angket motivasi yang dilakukan setelah pemberian materi pelajaran selesai.

d) Tahap Analisis dan Refleksi

Pada tahap ini dilakukan analisis terhadap pelaksanaan proses pembelajaran sejarah serta penguasaan materi yang diwujudkan dalam nilai tes dan motivasi melalui angket. Data yang 
diperoleh dari beberapa sumber data mencakup informan, tempat, peristiwa dan perilaku serta dokumen yangdiperoleh melalui observasi, tes, angket dan dokumentasi. Maka peneliti melakukan analisis data secara kualitatif. Setelah dianalisis peneliti dan guru yang bersangkutan melakukan refleksi untuk menentukan perlu tidaknya untuk melakukan tindakan atau siklus selanjutnya. Apabila hasil tersebut telah mencapai indikator keberhasilan maka tindakan atau siklus dapat dihentikan. 


\section{Daftar Pustaka}

Martanto, SD, dkk. 2009. 'Pembelajaran Sejarah Berbasis Realitas Sosial Kontemporer Untuk Meningkatkan Minat Belajar Siswa'. PKM-GT. Semarang. Tidak Dipublikasikan

Widja, I Gde. 1989. Dasar - Dasar Pengembangan Strategi Serta Metode Pengajaran Sejarah. Jakarta : Debdikbud

Alfian, Magdalia. 2007. 'Pendidikan Sejarah dan Permasalahan yang Dihadapi'. Makalah. Disampaikan dalam Seminar Nasional Ikatan Himpunan Mahasiswa Sejarah Se-Indonesia (IKAHIMSI). Universitas Negeri Semarang, Semarang, 16 April 2007

Hariyono. 1995. Mempelajari Sejarah Secara Efektif. Jakarta : Pustaka Jaya

http://e-journal.unipma.ac.id/index.php/JA/article/view/764/697

https://journal.ikippgriptk.ac.id/index.php/sosial/article/view/428/410

https://suciptoardi.wordpress.com/2009/07/28/pembelajaran-sejarah-

permasalahan-dan-solusinya/

http://repository.unpas.ac.id/12700/4/BAB\%20I.pdf 